\title{
The Impossibility of Republican Freedom
}

\author{
Preprint version. Forthcoming in Philosophy \& Public Affairs (Feb 2017) \\ thomas.simpson@bsg.ox.ac.uk
}

According to Philip Pettit's influential account of republicanism, freedom, which must be the primary concern of government, consists in non-domination rather than non-interference. Pettit argues that republican freedom is feasible; I argue here that it is impossible. For the people to be free from domination by the government, they must have the power to resist it. But if they have this power, they must also have the power to dominate any individual. There is thus a contradiction at the heart of Pettit's republicanism: the citizens must be powerful, but they also must not be. Individual citizens are dominated either by the state or by the people.

Republicanism has traditionally emphasised the necessity of civic virtue. Although parts of Pettit's work suggest that he endorses this view, he cannot do so consistently. His conception of freedom as non-domination allows him to give at most a contingent, instrumental role to civic virtue. He must reject any stronger reliance: civic virtue must not be necessary for freedom. For if one must rely on others' virtue to keep them from restricting one's freedom, one would then be subject to another's will and so dominated. Instead, institutions must ensure that individuals are free. My critique vindicates the traditional view.

The structure of the paper is as follows. I outline Pettit's republicanism, identifying some central claims $(\S 1)$. I then present two cases that-if they are both instances of domination, as I argue — entail that citizens are always un-free ( $\$ 2)$. I develop the objection by rebutting possible replies, showing that Pettit is committed to the possibility of what I term 
'polyadic' domination ( $\S \S 3-4)$. In conclusion, I distinguish my objection from other critiques, and defend the traditional republican view that civic virtue is necessary for freedom $(\S 5)$.

\section{Freedom as non-domination}

The case for republicanism is often made by appeal to this example:

\section{Master-Slave}

A benevolent Master allows her Slave to do as he wants. He does so but only by her leave.

This shows that non-interference is not extensionally equivalent to non-domination, and suggests that the latter is a more important form of freedom than the former.

Suppose a person, A, has a choice among various options. On Pettit's account, A enjoys freedom as non-interference-liberal freedom - if her choice is unrestricted. That is, if A decided to take one of those options, she would be able to; and there is no other agent, B, who has restricted the choice, or is likely to restrict it, by removing options or attaching a penalty to any. A enjoys freedom as non-domination - republican freedom - to the extent that there is no B who has a power of interfering in her choice in a way that is not controlled by A. B's power of interference is controlled by A if it can be exercised only on terms imposed by A; that is, and in Pettit's formulation, in a direction that A has the influence to determine. ${ }^{1}$

According to Pettit's account, liberal freedom does not entail republican freedom. Nor does republican freedom entail liberal freedom. My outline of his theory summarises the argument for and significance of these central non-entailment claims. In outlining his theory, I

\footnotetext{
${ }^{1}$ Philip Pettit, On the People's Terms: A Republican Theory and Model of Democracy (Cambridge: Cambridge University Press, 2012), pp. 49-56.
} 
identify two important claims that he makes, which I term the Externally Controlled Will Requirement and the Power of the People. I adopt these as premises in my counter-argument and, by reductio, I will ultimately reject the former.

First, it matters for Pettit that liberal freedom does not entail republican freedom because, according to him, their logical independence helps to show that non-domination is the more important kind of freedom. This is the starting point for the argument. Even though there may be no restriction on A's choice, she is dominated, and so not free, if there is someone who has the power to restrict her choice. Master-Slave is the dominant illustration. Others include the horse that, while being 'given its head', carries a rider with reins. Or doors left open, but with a doorkeeper able to shut them at will. ${ }^{2}$ It does not matter how probable it is that the doorkeeper will use his power. It is enough that it is possible for him, at will, to shut any door. Interference can take either of two forms. It can be a specific obstacle, such as a road-block that prevents one from being able to drive to the city centre, or it can be a general obstacle, such as a shortage of fuel that prevents one from being able to drive not only to the city centre but anywhere. Specific obstacles, which Pettit terms 'invasions', are the kind of interference of particular concern. ${ }^{3}$

Second, republican freedom does not entail liberal freedom, because one can be free from domination even when one's freedom as non-interference is restricted. Imagine, for example, that in an effort to regulate my alcohol consumption, I give you the key to my alcohol cabinet, and get you to promise to give it to me not less than $24 \mathrm{hrs}$ after I request it. When you comply with my request, you restrict my choice, but you do so under my control.

\footnotetext{
${ }^{2}$ Pettit, People's Terms, pp. 66, 156. Also Philip Pettit, The Robust Demands of the Good: Ethics with Attachment, Virtue, and Respect (Oxford: Oxford University Press, 2015), pp. 81-84.

${ }^{3}$ Pettit, People's Terms, pp. 38-44.
} 
So you can interfere with my choice but not dominate me. ${ }^{4}$ For A to control B's interference, it is essential that the limits on B's interference are not merely 'internal' to him. It is only when one controls another person's ability to interfere in one's life that that person's power to interfere does not constitute domination. In the alcohol example, it may be that you return the key to me only with $24 \mathrm{hrs}$ notice. If you do so because I irritate you and you wish to frustrate me, however, or even out of goodwill—say, for paternalist reasons — then you dominate me. 'Freedom requires independency of the will of others, even the goodwill of others' ${ }^{5}$ Not only is a benevolent will compatible with domination, so too is the morally committed will. 'Even if I form the view that it is wrong to interfere with you, it remains the case that I may prefer to practise interference, whether out of weakness of will, out of malice, or out of a will for evil ... [M]y domination over you can only be contained by external checks that remove or replace the interference option or put it cognitively off the menu' ${ }^{6}$ To summarise, only the externally controlled will to interfere does not dominate. Call this the Externally Controlled Will Requirement. It is easy to see how essential it is for the project. If, contrary to the Requirement, a merely internal check on the will of the powerful were sufficient for freedom, then Master-Slave would not be an example of a lack of freedom.

\footnotetext{
${ }^{4}$ Pettit, People's Terms, pp. 57, 152. In Pettit's early formulation of his theory, interference was dominating only if it was arbitrary. 'Uncontrolled' has replaced 'arbitrariness' as the condition for interference to be dominating. Compare Philip Pettit, Republicanism: A Theory of Freedom and Governance (Oxford: Clarendon Press, 1997), pp. 22-26; and People's Terms, p. 58.

${ }^{5}$ Pettit, People's Terms, p. 184. Also pp. 37, 59, 171; and Pettit, Robust Demands, pp. 84, 86.

${ }^{6}$ Pettit, People's Terms, p. 63; italics added. He formulates the criterion in a slightly more specific way elsewhere. For me not to dominate you, the check on my will must be exogenous, or be endogenous but in a disabling way, as a phobia is. See Philip Pettit, "Republican Freedom: Three Axioms, Theorems," in Republicanism and Political Theory, eds. Cécile Laborde and John Maynor (London: Routledge, 2008), pp. 10230, p. 124. The 'will for' and related 'will to' locutions are Pettit's.
} 
Pettit applies the account politically. Other people might have the power to invade some particular person but the state averts this 'horizontal' domination, dominium, by protecting the one individual from the others. It does so by enforcing the criminal law, which is a system of external checks on private interference. The state also enacts policies in pursuit of social justice. But both these powers of the state restrict the individual's choices; public interference has replaced private interference. As a group agent, the state also possesses a will. ${ }^{7}$ The individual is thus exposed to a new threat of 'vertical' domination by the state, imperium. As a practical consequence of its power to punish criminals, the state has the power to invade any particular individual.

If, however, each citizen can control the state's interference with her, the state does not dominate her. If the state imposes the criminal law and undertakes policy interventions on her terms, in a direction or according to a pattern that she has influence to determine, then she is not dominated. She has such control if she has a share in influencing government that is equal to that of every other citizen. She cannot demand more, because that would be to dominate her co-citizens. ${ }^{8}$ The processes of representative democracy initially realise this control through elections and legislative assemblies. If each citizen's equal influence on the state were by its leave, however, then government would be 'a law to itself' ${ }^{9}$ She would not control the state, and it would still dominate her. Ultimately, it is the work of the people - that is, the citizens - to protect her from domination by the state. The people exercise control through a disposition to resist an unresponsive government. This disposition is realized through voting, protest, civil disobedience and at the limit revolution. A people achieves

\footnotetext{
${ }^{7}$ Christian List \& Philip Pettit, Group Agency: The Possibility, Design, and Status of Corporate Agents (Oxford: Oxford University Press, 2011).

${ }^{8}$ Pettit, People's Terms, p. 167. While Pettit's elucidation of control as 'influence to determine' is suspect, I do not challenge it. See $\S 4 . i$ and fn. 39.

${ }^{9}$ Pettit, People's Terms, pp. 24, 218.
} 
freedom as non-domination when they have a 'resistive culture', and their government is averse to provoking their resistance. ${ }^{10}$ Call the claim that the citizenry control the government through their disposition to resist, by which they have the power to impose external checks on the government, the Power of the People.

The Power of the People is crucial if republican freedom is to be not only feasible, but even possible. As states are powerful and we live on a state-bound planet, there must be a way that states can serve the ideal of republican freedom. ${ }^{11}$ The division of political labor-with protection from dominium being the work of the state, and protection from imperium being the work of the people- provides it.

I turn to critique.

\section{Domination by coordinating agents}

In the following two cases, Slave suffers no loss of freedom as non-interference. The question is whether the Masters nevertheless dominate him. The cases involve people acting jointly, or as I shall say, coordinating. There are various analyses of joint action, but I assume here that it involves adopting a joint intention, and engaging in team reasoning. ${ }^{12}$ For example, a pair acts jointly when one goes up a ladder and the other holds it steady. They do not need to form a group agent to coordinate their action.

\footnotetext{
${ }^{10}$ Pettit, People's Terms, pp. 219; also 170-74.

${ }^{11}$ Pettit, People's Terms, p. 161. On the feasibility of republican freedom, see Pettit, Republicanism, pp. 206ff.; People's Terms, pp. 89, 180-81; Philip Pettit, Just Freedom: A Moral Compass for a Complex World (New York: W. W. Norton, 2014), p. 100.

${ }^{12}$ On joint intention, see John Searle, "Collective Intentions and Action," in Intentions in Communication, ed. P. Cohen, J. Morgan and M. Pollack (Cambridge: MIT Press, 1990), pp. 401-15. On team reasoning, see Natalie Gold \& Robert Sugden, “Collective Intentions and Team Agency,” Journal of Philosophy 104 (2007): 109-37. The content of one's preferred analysis of joint action may be easily substituted.
} 


\section{Nearly Coordinated Masters}

There are three Masters and a Slave. No Master is strong enough alone to interfere with the Slave. If two of them coordinate, they can interfere. Master ${ }_{1}$ is ready to interfere, but Master $_{2}$ and Master $_{3}$ are benevolent, rejecting the proposed joint intention and not engaging in team reasoning.

Slave is dominated here, and plainly so, by Master 2 and Master $_{3}$. A change in the will of either would result in uncontrolled interference. Slave does what he wants but only by their leave. (He is not dominated here by $\mathrm{Master}_{1}$, for she lacks the power to do anything that would, in the circumstances, result in interference with Slave.)

\section{$\underline{\text { Non-Coordinating Masters }}$}

As Nearly Coordinated, but all three Masters are benevolent.

I argue that Slave is, again, dominated. A change in the will of the Masters would result in uncontrolled interference. He does what he wants, but only by their joint leave. Here are two parity arguments, each showing that considerations that show Slave to be dominated in Nearly Coordinated apply also in Non-Coordinating. The parity arguments give pro tanto reason for a verdict of domination in the Nearly Coordinated case.

First, ingratiating himself with his Masters is an apt strategy for the Slave in both cases. In the Nearly Coordinated case, Slave does well to ingratiate himself with Masters $2 \& 3$, because by doing so he makes it less likely that he will be interfered with. This is one reason why a verdict of domination is plain in that case. It is part of Pettit's argument for construing freedom in terms of non-domination rather than non-interference that, if one needs to 
ingratiate oneself, one is not free. For Pettit, you 'cannot make yourself free ... by cozying up to the powerful and keeping them sweet'. ${ }^{13}$ There 'must be no be dependence on the good graces [of the Masters]'; the aptness of ingratiation shows Slave to be acting 'under the yoke of [their] will'. ${ }^{14}$ But the difference between the Nearly Coordinated and Non-Coordinating cases is simply a difference in Master ${ }_{1}$ 's intentions. For Slave to be in danger, it would require two Masters to turn against him, not one, but he remains dependent on their good graces. Ingratiation is still an apt strategy. That it is rational for Slave to ingratiate himself with the Masters shows that he is not free, in neither the Non-Coordinating nor the Nearly Coordinated case.

Second, the considerations that motivate the Externally Controlled Will Requirement also support a verdict of domination in Non-Coordinating Masters. Fill out the two cases with the situation of a Dalit ('Untouchable') in a rural area of India, breaking a caste norm—such as taking water from a communal well also used by upper castes. Within living memory, Dalits were lynched for this, often on the instigation of Brahmins, the highest of the traditional castes, and they remain vulnerable to caste-based violence. Suppose the Dalit is a physically strong young man, carrying a knife as self-protection, well able to defend himself against a lone attacker. While pumping water, the Dalit notices an angered Brahmin, looking to incite someone else so that they can together attack him. The Dalit is certainly dominated. $\mathrm{He}$ is in the situation of the Slave in the Nearly Coordinated case, dependent on other bystanders not to decide to join with the Brahmin in an attack. He is subject to the Brahmin's will. Now imagine that each villager has come to repudiate the caste system as a tool of oppression, and is convinced of the dignity of each person regardless of birth. Caste norms

\footnotetext{
${ }^{13}$ Philip Pettit, "The Instability of Freedom as Noninterference: The Case of Isaiah Berlin,” Ethics 121 (2011): 693-716, at p. 705; also Philip Pettit, "Freedom and Probability: A Comment on Goodin and Jackson," Philosophy \& Public Affairs 36 (2008): 206-20, at p. 216.

${ }^{14}$ Pettit, People's Terms, pp. 66-67.
} 
have no social power. The Dalit now pumps water without even thinking of possible threats. His situation is akin to the Slave in the Non-Coordinating case. The only reason for supposing that the Dalit is not dominated is the internal change in the villagers' moral convictions. But according to the Externally Controlled Will Requirement, this is irrelevant to whether he is free. The villagers' moral commitments are not a disabling internal constraint on what they do. They could repudiate their convictions and attack as easily (or with as much difficulty) as the Master could repudiate her benevolence and interfere in Master-Slave. Nothing else restrains the villagers from attacking. It does not matter how improbable it is that the villagers will attack. That there is no external constraint to their doing so means that the Dalit is subject to their will. Because the Masters do not satisfy the Externally Controlled Will Requirement in Non-Coordinating any more than they do in Nearly, Slave is dominated. As before, this is for reasons of the sort that Pettit himself gives.

If this is right, republican freedom is impossible. A person is dominated by a collection of agents who have an uncontrolled power to invade her, by coordinating. It does not matter how improbable it is that they will do so; the possibility that they may makes her un-free. No one can protect her from this interference except other people. But they too have the same power to coordinate, so the same danger arises again. One can ensure that one is not dominated by living in isolation. But this option is unattractive, and Pettit rules it out. ${ }^{15}$ Hobbes observed that, in the state of nature, 'the weakest has strength enough to kill the strongest, either by secret machination, or by confederacy with others'. ${ }^{16}$ Just by living among other people, one exposes oneself to the risk of confederacy. When that risk is present, one is dominated.

\footnotetext{
${ }^{15}$ Pettit, Republicanism, p. 66; People's Terms, p. 91.

${ }^{16}$ Thomas Hobbes, Leviathan, ed. Richard Tuck (Cambridge: Cambridge University Press, 1996), p. 87.
} 
One might suggest that, even if not everyone can enjoy republican freedom, at least some people may, and we should maximise the number who do. Anne Philips's question about the plausibility of a republican alliance with feminism suggests that it may be no accident of the republican tradition's history that the privileges of the liber (the free) were restricted to aristocratic men. ${ }^{17}$ That would be damaging enough, given that everyone should be able to enjoy republican freedom. ${ }^{18}$ The problem is more serious. All who live in society are vulnerable to confederacy_kings, presidents and generals too. Republican freedom is not possible for anyone.

Pettit may reply in one of four ways to this challenge. First, he could contest the premises of my argument. This response raises the deepest issues about the nature of domination and the prospects of his account to vindicate the possibility of freedom; I address it in the next section. The second and third possible replies derive from the ways in which, in Pettit's framework, one can be rescued from domination even if someone has the power to interfere. The fourth reply accepts the conclusion but seeks to mitigate its significance. I address these latter replies in the penultimate section.

\section{The Power of the People}

The most plausible reply for Pettit is to accept that Slave is dominated in Nearly Coordinated, but deny this in Non-Coordinating. He might argue as follows. Domination is a relation between two wills only, in which B dominates A. This is not a mere report of intuition. It follows from the basic case for the superiority of republican freedom over liberal freedom. You are not free if I have the power, at will, to close the doors in any doorway you might try

\footnotetext{
${ }^{17}$ Anne Philips, "Feminism and Republicanism: Is This a Plausible Alliance?" Journal of Political Philosophy 8 (2000): 279-93. Also Robert E. Goodin, "Folie Républicaine," Annual Review of Political Science 6 (2003): 5576, at pp. 61-66.

${ }^{18}$ Pettit, People's Terms, pp. 8, 93ff.
} 
to go through. I have the power to close a door at will only if my ability to do so does not depend on anyone else's decision. If I depend on a collaborator, and my collaborator is unwilling, then I am not able close the door at will. You are subject to the will of my collaborator, in the way that Slave is in the Nearly Coordinated case. But you are not subject to $m y$ will. For A to be dominated, there has to be a B who can determine, in the circumstances, whether A is invaded. When B has the power to invade A at will, one can say that there is 'dyadic' domination, which is a relation between the members of a pair. In summary, the reply claims that all domination is dyadic.

Niko Kolodny proposes a test for determining when A is subject to B's will that supports the claim that all domination is dyadic. Without endorsing it, he suggests that the following Can Do test should be ascribed to proponents of the 'Kantian-Republican thesis', according to which being under the power of others is objectionable as such. ${ }^{19}$ Imagine that B were to will to invade A. Hold fixed, to the extent possible, everything else, including the wills of all other agents. Then ask whether B invades A. If so, B has the power to invade A, and dominates her; otherwise he does not. (This is easily amended to test for any 'power to' relation between $\mathrm{B}$ and $\mathrm{A}$.)

The Can Do test accurately expresses the need to exclude changes in the will of third parties from consideration. This ensures that it identifies as instances of domination only those situations in which B's will to invade is decisive in the circumstances. The test must not allow changes in the will of people who are protecting $\mathrm{A}$, such as the state, and those in its public positions. Otherwise it would not be possible to rely on the state to protect individuals from private interference. The 'hold fixed' clause ensures that the test does not make this

\footnotetext{
${ }^{19}$ Pettit is an exemplar of the thesis. I am greatly indebted to Kolodny's discussion in his “Being Under the Power of Others" more generally. Available at $<$ http://sophos.berkeley.edu/kolodny/BeingUnderThePowerOfOthers4.pdf $>$, accessed 22 December 2016. See fn. 40 for further on the relations between his paper and mine.
} 
error. Further, the test is restricted so that it applies only to single agents with a will. Conjoining this restriction with the 'hold fixed' clause means that, by applying the Can Do test, one recognises only dyadic instances of domination.

By applying the Can Do test, one can see how to justify the different verdicts in the cases, in the way that this suggested reply requires. There is dyadic domination in the Nearly Coordinated case, twice over in fact. Imagine that Master $_{2}$ intends to invade Slave. Hold fixed the wills of all other agents. Slave is then invaded, by Masters ${ }_{1} \& 2$ together. So Master 2 dominates Slave, as does Master $_{3}$, by parallel reasoning. In contrast, there is no dyadic domination in the Non-Coordinating case. When one applies the Can Do test to each of the three Masters in turn in that case, one finds that Slave is not invaded. By that test, none of Masters $_{1-3}$ dominate Slave. If all domination is dyadic — which follows from the basic case for conceiving of freedom as non-domination-then the verdict that Slave is not dominated in that case is well supported.

I think, however, that it is a mistake to suppose that all domination is dyadic. Rather, some domination is 'polyadic'. Polyadic domination is the relation that holds between some group of people, G, and A, when, by acting in a coordinated way, the members of $\mathrm{G}$ have the uncontrolled power to interfere with A. The Non-Coordinating case is an example of polyadic domination. Indeed, Pettit's own account commits him to the possibility of polyadic powers of interference. This is because, without this possibility, the Power of the People is false. I now explain why this is so.

The people belong to an additional category in Pettit's social ontology. That ontology prominently includes agents that have a will, namely individuals and group agents, and he has well developed accounts of these. His test for personal agency is 'conversability', when one can talk to and engage with that agent to mutual benefit. As a precondition of conversability, 
the agent must be reliably rational in having attitudes that are consistent. ${ }^{20}$ Group agents are conversable. ${ }^{21}$ The people are not. Many individuals propose to speak on behalf of the people, of course. But - other than through the processes of political representation, which are part of the state-citizens do not have a way to decide who speaks on their behalf, or to reconcile inconsistent attitudes. As they are not conversable, they do not constitute a group agent. Nonetheless, they exercise together an ability that individual members do not have, that of resisting the state. Although it is vague how many must resist for the state to be controlled by the people, sufficiently many of the people must impose checks on it when it does not respond to their direction.

In Pettit's terms, it is difficult to identify this as anything other than a power to interfere with the government. One possible alternative is to suppose that, in this instance, 'power' describes not the capacity of agents to act intentionally, but the potential of a nonrational force, in the way that the sea is powerful. The power of the people to resist the state would be more like a process of physical causation. But this is not right; individuals impose checks on the state by their intentional action.

Another alternative is a reductive analysis, which proposes that 'the' power of the people should be read as misleading shorthand for many individuals' discrete powers. There is more to say on this reductive strategy, but it should be rejected, and by Pettit as well. Consider his example of holiday-makers on a beach, who form a chain to pull a swimmer out of difficulty. This is not an instance of group agency. It is instead an instance of joint action, which, as noted, I assume to require joint intentions and team reasoning. ${ }^{22}$ The power of

\footnotetext{
${ }^{20}$ List \& Pettit, Group Agency, pp. 24-31.

${ }^{21}$ Philip Pettit, "How to Tell if a Group is an Agent," in Essays in Collective Epistemology, ed. Jennifer Lackey (Oxford: Oxford University Press, 2014), pp. 97-121, at pp. 108ff.

${ }^{22}$ Compare Pettit, "How to Tell”, p. 116, n. 12.
} 
rescue exists only collectively, not distributively. That is, the holiday-makers jointly have the power to rescue the swimmer. But each person individually does not.

The reductive strategy denies this; it claims that 'the' rescue by the group is an aggregate of individual actions, which together constitute a rescue. Properly speaking, the power to rescue existed only when the chain was in place. The members of the chain did not have the power to rescue the swimmer; each had the power only to lock arms, and so on. The only people who had that power were those who, once the chain existed, could rescue the swimmer.

A problem with this strategy is that there are some examples to which it cannot be applied. Imagine that launching a nuclear strike requires the President, the Minister of Defence, and the Chair of the General Staff to turn their keys exactly simultaneously; that is, within a time period in which one person's decision cannot be revised in light of another's. The three have the power to launch a nuclear strike, but they have it only collectively. Another problem is that the strategy implies that the power to rescue does not exist when it does. The holiday-makers see the swimmer in difficulty; someone shouts, 'Can we save him?'. It is not just psychologically implausible to answer 'No'; it describes the phenomena wrongly. The holiday-makers, together, have the power to rescue the swimmer, even though-because the chain is not yet formed — no individual does. Decomposing the joint action into individual actions, and recognising only individuals' ability to do what is within their power, fails to recognise abilities that the group also possesses, without being a group agent. $^{23}$

\footnotetext{
${ }^{23}$ There may be collective powers that can be exercised without joint action. Perhaps ants lack intentionality, so do not have the joint intentions necessary for acting jointly, but ant colonies possess collective abilities. Further, not all joint actions are the exercise of a power that is collective only. But collective abilities that can be exercised by joint action alone — at least in practice, as in the beach case and, to anticipate, revolutions—are an important and distinct kind of social agency.
} 
The power of the people to control the state must be held collectively. Individuals are able to conduct some acts of resistance alone, such as civil disobedience or withholding tax. These powers to resist can be held distributively. But other powers to resist must be exercised jointly, and are held collectively. This is illustrated well by the limit case, revolution. No one alone has the power of revolution; individuals can merely perform component parts of a revolution. It needs a group to overthrow a government. Because revolutions must be possible for the Power of the People to be true, Pettit's scheme requires that some social powers be held collectively.

The importance of this point is made evident by applying the Can Do test to the people. The Can Do test does not recognise powers that are held collectively but not distributively, nor by a group agent. If the test is applied to each holiday-maker on the beach, the result is a judgement that no one has the power, alone, to rescue the swimmer. This is true enough. The Can Do test does not recognise that the power to rescue the swimmer nonetheless exists - not, at least, if we assume the test applies only to agents with a will. This suggests that something is wrong with the test. The test can also be applied to the people, so that it asks whether each person has the power to impose external checks on the state that are sufficient to control it. The result of applying this to each citizen individually is a judgement that no one does, because the asymmetry of power between the state and each citizen is too great. The exception is when sufficiently many other citizens have already imposed checks on the state, and one more person's resistance will be decisive. But that scenario is irrelevant in practice. Nonetheless, the people collectively do have the power to control the state. The application of the Can Do test to the case of the people confirms that something is wrong with it.

Once it is accepted that some social powers are held collectively, the analysis of lesser acts of resistance — such as protest marches—should be reconsidered. The power to protest 
can be held distributively; one-person protests are possible though lonely. But the power to protest can also be held collectively. A particular protest march may be the result either of individuals acting alone but at the same time, or of their acting jointly. In practice, effective resistance relies on the latter. Many forms of resistance are prudentially wise only if a group of people undertake them at the same time. Resistance is also more effective if many people act together. Citizens' control over the state, then, depends on their exercising power jointly. Given the power of the modern state, which Pettit largely endorses, the countervailing power held by citizens must be substantial.

So Pettit's social ontology must, and implicitly does, recognise a locus of social power other than individuals or group agents. As he does not give a term to groups that sustain this power, we can call them teams. Team members' action is coordinated but not necessarily directed. As a distinct form of social agency, there is a sense in which teams lie 'between' individuals and group agents. Teams have a degree of coordination that makes their action distinct from that which emerges from individuals interacting without any joint intention. But they do not have the degree of coordination that group agents require. Teams are not 'mere pretenders' to group agency. ${ }^{24}$ They exercise a different form of social agency.

Given that teams exist, the Can Do test must be revised. That test applies naturally to the central categories of Pettit's social ontology: individuals and group agents. They are agents with a will. If a team had a will, the Can Do test could be applied to it directly, with 'B' standing for the team. But we may suppose that teams do not have a will, because they are not conversable. This is why the Can Do test does not apply to them, and why it does not recognise powers exercised by people acting jointly. In failing to recognise the existence of powers that are held by people acting jointly, the Can Do test fails to recognise that the people have the power to impose checks on the state. Pettit relies on this to apply his account

\footnotetext{
${ }^{24}$ Pettit, "How to Tell”, p. 98.
} 
politically, and the fact is plain enough anyway. To serve its purpose - to identify the power to invade - the test must be amended.

The simplest way to do this is to create an additional test. Consider some agents, $a, b$, ... n, who could coordinate; as such, they are members of G. Imagine that each member of G were to will to invade A, by coordinating. To the extent possible, hold fixed everything else, including the wills of all other agents. Then ask whether they invade A. If so, then the members of $\mathrm{G}$ have the power to invade A, otherwise not. Call this the Can Do Together test. To apply it, one must resolve a prior counterfactual question, namely whether the agents could coordinate, by adopting a joint intention and engaging in team reasoning. But there is neither circularity nor reason to suppose that the regress is vicious. The Can Do Together test satisfies the requirement that changes in the will of third parties are excluded from consideration. In particular, the will of the state is held fixed, as are the wills of those in its public positions - except when these are members of G, a situation we want to test for anyway. To identify a power to invade, both the Can Do and Can Do Together tests must be applied. If there are other sources of social agency where there is no will, further tests must be identified for each.

According to the Can Do Together test, Slave is dominated in the Non-Coordinating Masters case. If each of Masters ${ }_{1-3}$ were to will to invade by coordinating, Slave would be invaded. The case is an instance of polyadic domination. This result is the basis of the dilemma that I posed in the opening paragraph of this article. The form of social agency by which the people control the state is the same as that exercised by the Masters in the NonCoordinating Masters case. If the Masters do not have the power to invade Slave in that case, then neither do the people have the power to impose checks on the state. That is, if Slave is not dominated in Non-Coordinating Masters, then the Power of the People is false. But if the Power of the People is false, everyone is dominated by a state, because we live on a state- 
bound planet. Conversely, if the Power of the People is true, then Slave is dominated in NonCoordinating Masters. For as the people control the state by their power to act in a coordinated way, so the Masters have the power to invade Slave. But polyadic domination is then possible, and individuals are always un-free. There are always collections of agents who could, by coordinating, invade any individual. It is exactly the people with whom that individual might control the state who dominate her. ${ }^{25}$ Either way, republican freedom is impossible.

The argument for the possibility of polyadic domination must also address the basic case for the superiority of republican freedom over liberal freedom, which provides a possible way for Pettit to resist this dilemma. The basic case for the superiority of republican freedom consists in an appeal to the value of not being subject to the will of another. I have presumed that the existence of a power to invade A is itself sufficient for A to be dominated. But Pettit may deny this, and allow that some powers to invade are not dominating. He could do so by stipulating that domination can be a dyadic relation only. To be dominated, there must be a $\mathrm{B}$, a change in whose will alone would result in my interference. If there is no such B, then I am not subject to the will of any individual. Non-dyadic powers to invade A would not result in A being dominated, even though they leave A at risk of being invaded. As the power to invade through coordinated action would be such a non-dominating power, it would thereby enable Pettit to deny the dilemma. The Power of the People would still be true, and Slave not be dominated in Non-Coordinating Masters. Pettit need not claim that the people dominate the state. He needs to show only that the people have the power to impose checks on it.

\footnotetext{
${ }^{25}$ The reasoning behind the dilemma shows that I do not claim or imply that domination is transitive. That claim is false, as Frank Lovett argues; see his A General Theory of Domination and Justice (Oxford: Oxford University Press, 2010), pp. 69-70.
} 
This stipulative reply is implausible. Being subject to the will of one other person may be psychologically more salient than being subject to the will of a group. But it is not clear, to me at least, why this alone should mark a morally significant difference, especially when my capacity to enjoy freedom as non-domination is sensitive to the possibility that others can decide to interfere with me, not to the probability that they will. Interference by a group is just as worrisome, perhaps more so, as interference by an individual. A group of agents may be less likely to interfere, but it is unclear why their collective capacity to do so at will should not compromise my freedom in the same way that an individual's capacity does. The distinction is unmotivated. Further, while Pettit may stipulate that domination is a dyadic relation only, there is a theoretical cost. Part of the price to pay is that non-domination is no longer a comprehensive conception of freedom. There are important losses of freedom that fall outside its scope. A further cost is that it disconnects freedom as non-domination from the considerations that were supposed to justify it, as identified by the parity arguments. Its promise is that, when you are free from domination, you no longer need to ingratiate yourself with the powerful or rely on others' decision not to interfere. But, like Slave in NonCoordinating Masters, you may have to. This attempt to resist the dilemma therefore fails in Pettit's own terms.

There is a different, though I think less plausible, way for Pettit to contest the premises of my argument that is suggested by the above remarks. He might deny that Slave is dominated in Nearly Coordinated Masters as well as in Non-Coordinating Masters. Not all possible sources of interference, as such, compromise republican freedom-I do not dominate you just because I may develop super-human powers. ${ }^{26}$ To compromise freedom, the capacity to interfere arbitrarily must be 'more or less ready to be exercised'. According to Pettit, one possibility that does not compromise republican freedom is the prospect that a hugely

\footnotetext{
${ }^{26}$ Pettit, People's Terms, p. 68.
} 
powerful group agent may incorporate. While possible incorporation poses 'virtual' or 'potential' domination, there is no actual domination. ${ }^{27}$ Incorporation is relevant to the degree of freedom I enjoy only insofar as its occurrence is probable; its mere possibility is irrelevant. ${ }^{28}$ It might be argued that coordination is structurally similar to incorporation. Possible coordination may compromise freedom in the same way that possible incorporation does: only to the extent that it is probable, not if it is merely possible. Perhaps a power to act jointly exists only when those who could coordinate have adopted a joint intention and started the process of team reasoning. Because the joint intention has not been adopted in Nearly Coordinating or Non-Coordinating, no such power exists in either case.

It is particularly implausible to deny that there is domination in the Nearly Coordinated Masters case, because the considerations appealed to in the parity arguments apply with such force to that case. Consider how easy it is for a team to coordinate. Master 1 has declared her desire to interfere by acting jointly with someone else. If one other Master decides to join her, Slave will be dominated. If we treat this case the way Pettit claims we should treat cases in which incorporation is unlikely but possible, we must accept that Slave is not subject to the will of another. Yet he seems clearly subject to the wills of the other Masters, for all it would take for him to be invaded would be for one of them to change her mind. Pettit may stipulate that coordination occurs only when the joint intention has been adopted. Again, there is the same theoretical cost. This stipulation would disconnect freedom as non-domination from the considerations that were supposed to justify it. Because it is rational for Slave to ingratiate himself with the Masters precisely because he does rely on Masters $_{1} \& 2$ not to decide to interfere, he is dominated in Nearly Coordinated according to the

\footnotetext{
${ }^{27}$ Pettit, Republicanism, pp. 54-55.

${ }^{28}$ Pettit, "Freedom and Probability”, p. 218; also People's Terms, pp. 67-68.
} 
considerations identified in the parity arguments. Polyadic powers to invade may be a form of domination.

I now address some further possible replies.

\section{Further replies}

(i) Control. Recall that, if an individual citizen controls any possibility of interference with her, she is not dominated. This point admits a possible reply. Polyadic domination can be avoided if I may control the actions of potential team members. Pettit argues that a citizen can control at least one collective agent, namely the state. She has control over the state if it accords her a share in influencing government that is equal to that of each other citizen; she cannot demand more, because that would be to dominate her co-citizens. The reply applies this to teams, and by application, to the people. If someone can have an equal influence on how a team acts, she may yet exercise enough control to prevent her from being dominated. This is so even if the team's action is contrary to her preference. In the Non-Coordinating case, Slave would not be dominated if he had an influence on any joint action by the Masters, and his influence on that outcome was equal to that of each Master.

While it is intuitively clear that this reply fails, it is worth identifying what the errors are. Suppose a gang attacks one of its members. Plainly, the victim lacks the required control over what the rest are doing, even if he has an equal influence on what the gang does. Likewise, a team member lacks control over what her team is doing, and a citizen control over what the people are doing, even if each has equal influence on the team and the people respectively. There are two objections. First, as noted, it is suspect that someone individually has control over a collective decision if his share of influence on the decision is tiny. It is 
unclear how it helps for that influence to be equal. ${ }^{29}$ But even if this were granted, second, it would be a mistake to suppose that this is sufficient for control. He must also have the ability to direct the other's action in a way that is 'modally robust'; that is, he must be able to direct what the other does in a sufficiently wide range of counterfactual circumstances. In particular, his ability to direct the other must be robust over possible changes in the latter's will. This is why Pettit requires not just that one have an equal share in influencing the government, through voting, but that the people are also disposed to resist it. If this 'unconditioned' popular control did not exist, one's equal share of influence on the government would be by its leave, and one would be dominated. ${ }^{30}$ But there is no way that one can exercise 'unconditioned' control over how the other members of a team act. Vagaries in the natural distribution of strength, charisma, and so on, mean that one's equal influence on other team members is not assured without the decision of others to grant it. Strategic reasoning does not bring them to that conclusion; it is de jure reasoning only that supports it. Whether one has equal influence on other team members depends on them and on their moral judgment. The equal influence one has is by their leave, and so one lacks unconditioned control. Even if the Masters granted Slave an equal influence to determine how they would jointly act, his influence is not unconditioned. It is not true of teams, and by application not true of the people's resistance to the state, that a member's equal influence on a team's action is sufficient for his individual control of that action. ${ }^{31}$

\footnotetext{
${ }^{29}$ This objection is argued well by Assaf Sharon, "Domination and the Rule of Law", in Oxford Studies in Political Philosophy Vol. 2, ed. by David Sobel, Peter Vallentyne, \& Steven Wall (Oxford: Oxford University Press, 2016), pp. 128-55, at pp. 139-40; and Kolodny, "Being Under”, at $\$ 2.4$.

${ }^{30}$ Pettit, People's Terms, p. 239.

${ }^{31}$ Both of these objections also count against the claim that a citizen's equal influence on a state, through the government-supported processes of participation such as voting, saves her from domination by that state. Sharon correctly applies the first objection against this target. But Pettit could, in fact, concede that point while retaining
} 
(ii) Protection. In Pettit's scheme, while one person may have a power of interference over another, a third party may protect the potential victim by imposing sanctions on the potential invader that take the option of invasion 'cognitively off the menu'. The central agent of protection in Pettit's scheme is the state, through the criminal law. The state cannot be the protector of last resort, however, because it is a collective agent and potentially an alien will. The people are the protectors of last resort. But the threat of polyadic domination, posed by exactly the same individuals who constitute the people, and the lack of my control over their actions, undermine that last claim. There is, however, a way that one may be protected from interference that is not susceptible to those problems. If there is an unintentional source of protection, one may enjoy non-interference without anyone's permission.

Pettit might suggest that social norms could play this role. 'Being disposed to approve of compliance and to disapprove of deviance, citizens can become non-intentional sources of

the substance of his account. If through her equal influence on the people an individual could control what the people do collectively, then that would be sufficient for her to control the state, even if her voting was insufficient for control—for what the people are doing is, in this instance, controlling the state. And given my account of how the people control the state, the pertinent question is whether a team member may control a team's action. Due to Pettit's division of political labor, then, according to which the people's control over the state prevents imperium, to object successfully that a citizen lacks control over the state one must show that an individual lacks control over the people.

This illustrates a surprising and unstated consequence of Pettit's account, namely that elections are not essential for democracy. Suppose that there was a way of revealing individuals' political preferences without elections, but which was as accurate; a process for deriving policy given these that ensured equal influence; and a resistive culture ensuring governmental compliance with the revealed preferences and the process. Then each person would have equal influence to determine what his or her government does. Pettit's conditions for control by the people would be meet-and without elections. Perhaps analysis of individuals' search engine enquiries, web browsing records, and social media postings could substitute for voting one day. 
enforcement'. ${ }^{32}$ Suppose there is a norm that renders uncontrolled interferers subject to sanction. Such a norm could then protect each person from interference. Grant that one's desire for others' approval and aversion to their disapproval is a brute psychological disposition, not susceptible to reasoning, and so is their disposition to bestow approval and disapproval. If flouting a norm is a trigger for unintentional attitudes of disapproval, and one's desire for those attitudes is also unintentional, one has reason to conform regardless of others' actions. This dynamic, unintentional process reinforces norms of which most people approve, helping to render the norms stable. One is protected, it seems, and in a way that depends on the will of none.

Enforced norms can play only a supporting role in ensuring republican freedom. The economy of esteem supports higher levels of norm-conforming behaviour than would be achieved by coercive sanctions alone. But for a norm to support individual freedom, individuals must depend on those who impose penalties on those who do not conform. When there is gain to be had, many people are undeterred by mere disapproval. Disapproval stops some theft, but hardly all; even less so murder. The norm must therefore be supported by material as well as expressive penalties. ${ }^{33}$ So one's freedom depends on others' action; that is, one depends on their will. Perhaps machines may become sources of unintentional protection. People are not.

(iii) Unperturbed domination. A final, deflationary reply to my initial challenge accepts that there is polyadic domination in everyday life. But it seeks to mitigate its significance, claiming that the domination is not very serious. Moreover, it is not a critical objection that governments cannot eliminate domination; they may reasonably aim to

\footnotetext{
${ }^{32}$ Pettit, People's Terms, p. 129; italics added.

${ }^{33}$ Contrary to Pettit, who supposes that expressive penalties may be sufficient to support a norm. See Geoffrey Brennan and Philip Pettit, The Economy of Esteem: An Essay on Civil and Political Society (Oxford: Oxford University Press, 2004), pp. 274-79.
} 
minimise it. ${ }^{34}$ Domination comes in degrees. How substantial B's domination of A is depends on the domains of A's life in which A's choices are subject to B's uncontrolled power to invade, the ease with which B is able to invade A's choices, how important those choices are, and so on. ${ }^{35}$ One might argue that, in these respects, polyadic domination is in practice neither severe nor easily exercised by would-be interferers.

This is not so; polyadic domination is severe. But this charge is the hardest reply to argue against, because our perspective diminishes our ability to perceive the ease with which joint power can be exercised. I say 'our' perspective advisedly, as readers are likely to be located in prosperous, stable parts of the world. Life in these areas has become both individualised and institutionalised, so that spontaneous joint action is not seen often and not readily imagined. Common space has increasingly become a thoroughfare to take us to places designated for specific, routine activities, rather than a place for social interaction. We are outliers in this. In the relatively recent past and in the majority of the world, where these trends are less pronounced, spontaneous group action was and is a salient possibility. There are positive dimensions, such as the capacity for celebratory exuberance, as well as negative, destructive ones too. Where governance is weak or non-existent, violence is less a rupture from the routine, and is more part of the fabric of life. While the situation of Dalits in India is an example, minorities in the West attest that the capacity for such action is depressingly present too. It is a triumph of governance when this is unlikely. But the degree to which B dominates A is not affected, according to Pettit, by how likely it is that B will invade. In particular, whatever internal constraints B may have, which make it unlikely that he will invade, do not affect A's degree of freedom. So too for coordinating agents. Joint invasion is

\footnotetext{
${ }^{34}$ As proposed by Lovett, General Theory, pp. $187 \mathrm{ff}$.

${ }^{35}$ Pettit, Republicanism, pp. 57-8, 75; People's Terms, p. 85.
} 
always a possibility; it is easy; and the consequences are serious. Polyadic domination is substantial.

\section{Virtue and freedom}

In concluding, I will clarify how my charge of polyadic domination is distinct from other critiques, and note a positive lesson to be drawn.

Since the publication of Republicanism, the dominant lines of criticism have been either practical or analytical. The practical line of criticism has charged that, while republican freedom may be a distinct conception of freedom, non-domination is of restricted or no practical significance. The theory may describe something important about what it is to be free, but there is no direct way to make political use of it. Critics have argued that republicanism does not yield determinate policy implications, that knowledge of arrangements for republican freedom presupposes knowledge of arrangements for liberal freedom, that non-domination is not the only political ideal, and not the primary policy aim of government, and that the independence of others required cannot be achieved under non-ideal conditions, so that republicanism is too demanding. ${ }^{36}$ My charge is theoretical, not practical. In particular, it is not a version of the non-ideal theorist's complaint against ideal theory. Even with a universal disposition to comply fully with the law and morality, the obstacle to invading jointly is internal. Polyadic domination still exists in the Kantian kingdom of ends,

\footnotetext{
${ }^{36}$ Respectively: Christopher McMahon, “The Indeterminacy of Republican Policy,” Philosophy \& Public Affairs 33 (2005): 67-93; Boudewijn de Bruin, "Liberal and Republican Freedom," Journal of Political Philosophy 17 (2009): 418-39; Patchen Markell, “The Insufficiency of Non-Domination,” Political Theory 36 (2008): 9-36; Pablo Gilabert, "Solidarity, Equality and Freedom in Pettit's Republicanism," Critical Review of International Social and Political Philosophy 18 (2015): 644-51.
} 
in which all are saints wholly committed to respecting others. ${ }^{37}$ As I argued above, it is not even possible to reduce its severity.

The analytical critique focuses on whether Pettit's account of non-domination describes a kind of freedom distinct from the liberal category of non-interference. Critics dispute both of the non-entailment theses stated in the introduction. They argue that everything valuable about republican freedom, including the assurance it provides, can be made sense of by an appropriately formulated notion of liberal freedom - in particular, one that is sensitive to probability over time, such as expected non-interference. Further, conditions under which someone counts as being free in republican but not liberal terms are not well described as instances of liberty. ${ }^{38}$ Indeed, Pettit's statement that imprisonment need not take away freedom is the most compelling evidence for this. ${ }^{39}$ An alternative diagnosis of what is wrong in cases like Master-Slave develops this charge of misdescription. The real concern is unequal social status. This is related to freedom, but only contingently. Suppose Slave knows that his Master is not going to interfere, so that there is no point in his being

\footnotetext{
${ }^{37}$ This point is parallel to one made by Pettit, that without the state there would still be private (dyadic) domination in the Kantian kingdom of ends; see People's Terms, pp. 181-83.

${ }^{38}$ See Ian Carter, A Measure of Freedom (Oxford: Oxford University Press, 1999), pp. 237-45; Ian Carter, "How are Power and Un-freedom Related?" in Republicanism and Political Theory, ed. by Cécile Laborde \& John Maynor (London: Routledge, 2008), pp. 58-82; Matthew Kramer, The Quality of Freedom (Oxford: Oxford University Press, 2003), pp. 135-49; Matthew Kramer, "Liberty and Domination," in Republicanism and Political Theory, ed. by Cécile Laborde \& John Maynor (London: Routledge, 2008), pp. 31-57; Charles Larmore, "Liberal and Republican Conceptions of Freedom," Critical Review of International Social and Political Philosophy 6 (2003): 96-119.

${ }^{39}$ Pettit, Republicanism, p. 56.
} 
obsequious. That relationship is corrupt not because Master limits Slave's freedom, but because it involves subordination. ${ }^{40}$

I am sympathetic to these charges. Given the impossibility of republican freedom, moreover, any plausible conception of freedom must be primarily concerned with noninterference (or, perhaps, some form of positive freedom, or some combination of both). But the debate risks stagnation in a terminological standoff, where there is brute disagreement

\footnotetext{
${ }^{40}$ See Kramer, Quality, pp. 142-43; and at length and decisively, Kolodny, "Being Under". I should clarify the relation of my charge of polyadic domination to these two critiques. Kramer proposes that a gentle giant—who has overwhelming power but leads a reclusive life of foraging and meditation—both dominates and does not compromise freedom; see Quality, pp. 140ff. There is a structural parallel between his and my objections, in that both identify a power to invade without the will to. Kramer's example illustrates his charge of conceptual misdescription, however, while mine shows the impossibility of republican freedom. The gentle giant example cannot sustain the latter objection. Other things equal, republican freedom is possible if there are no gentle giants, as is true for us, or if the state has the power to protect the little people from the giant, as in Lilliput.
}

Kolodny's paper has a positive, diagnostic part, according to which the considerations that support republicanism (and that motivate Kantians concerned by domination) are best understood as worries about social subordination. It also has a negative part, in which he argues that the state dominates its citizens. Although his negative thesis and my own are orthogonal, there are two points of intersection in the arguments. Each rejects the possibility of unintentional protection. Kolodny considers law as a source, whereas I consider social norms (§§2.3 and 4.ii respectively; for a reply to Kolodny here, see Thomas Sinclair, "The Power of Public Positions," in Oxford Studies in Political Philosophy Vol. 4 (Oxford: Oxford University Press, Forthcoming)). Each also uses the observation that, even in situations of coordinated action, one lacks the control over others required to make the joint outcome one's own. Kolodny rejects this for democracy, arguing that for one to have an equal but tiny share in the formation of a collective agent's will does not give one control individually, and that the 'influence to determine' locution hides this ambiguity (see fn. 31 above). I endorse that criticism, though the nature of my point is different; I argue that one does not have unconditioned control over a team's action (see $\S 4 . i)$. The Dalit example is shared. Kolodny uses it to illustrate his positive claim. I was in Ahmedabad, India, at the time of writing, where anti-Muslim riots by the Hindu nationalist majority years ago have left a mark on the consciousness of the city. This did much to make salient to me the possibility of polyadic domination. 
over whether someone else's uncontrolled power to interfere compromises freedom. ${ }^{41}$ (Compare, for example, "She will not interfere, but she could" with "She could interfere, but she will not". The former invites the republican's conclusion; the latter that of the "pure negative liberty' theorist.) Nonetheless, if the charge is sustained that the wrong in MasterSlave is subordination, an initial positive lesson can be drawn. The important enquiry in this area of practical philosophy is into the political implications of social equality, including the influence this should have on government, given other moral ideals, notably freedom. There is much good work being done on this. ${ }^{42}$ The principal positive lesson I draw here, though, concerns the soundness of a central claim from the civic republican tradition. I state it first in the terms of Pettit's framework.

The central lesson concerns the analysis of freedom. If freedom is to be a possible ideal, let alone a feasible one under non-ideal conditions, one's freedom must be compatible with one's being exposed to others' power of interference. It must be possible for one to be free, with the control on the non-interference of some others being 'internal' only. Because the Externally Controlled Will Requirement cannot be satisfied as a general condition on freedom, it must be rejected. People who have sufficient internal controls do not threaten my freedom. The conditions for control will normally be expressed in terms of something like responsiveness to right reasons or right ends for action, with that content more or less

\footnotetext{
${ }^{41}$ See Pettit, "Three Axioms, Four Theorems", pp. 118-25, and 128, n. 23.

${ }^{42}$ E.g. Niko Kolodny, "Rule Over None I: What Justifies Democracy?” Philosophy \& Public Affairs 42 (2014): 195-229; Niko Kolodny, "Rule Over None II: Social Equality and the Justification of Democracy" Philosophy \& Public Affairs 42 (2014): 287-336; and the papers collected in Social Equality: On What it Means to Be Equals, ed. by Carina Fourie, Fabian Schuppert \& Ivo Wallimann-Helmer (Oxford: Oxford University Press, 2015).
} 
specified. Some feminist analyses of the concept of domination have already made this revisionary move. ${ }^{43}$ I here reinforce and add to their argument.

The lesson for the republican tradition is that civic virtue is vindicated as necessary for liberty. Quentin Skinner identifies two main approaches to virtue and corruption in political thought since the Renaissance.

One stresses that government is effective whenever its institutions are strong, and corrupt whenever its machinery fails to function adequately. (The greatest exponent of this outlook is Hume.) The other approach suggests by contrast that if the men who control the institutions of government are corrupt, the best possible institutions cannot be expected to shape or constrain them, whereas if the men are virtuous, the health of the institutions will be a matter of secondary importance. This is the tradition (of which Machiavelli and Montesquieu are the greatest representatives) which stresses that it not so much the machinery of government as the proper spirit of the rulers, the people and the laws which needs above all to be sustained. ${ }^{44}$

The endorsement of the latter approach is central to the republican tradition. 'It is as a politics of virtue that republicanism most clearly defines itself ${ }^{45}$ Civic virtue-which requires fairminded political engagement by citizens and dedicated public service from leaders - is crucial to the stability of a free, self-governing polity because both its requirements are bulwarks

\footnotetext{
${ }^{43}$ Eva Feder Kittay, Love's Labor: Essays on Women, Equality, and Dependency (Oxford: Oxford University Press, 1999), pp. 33-34; Marilyn Friedman, "Pettit's Civic Republicanism and Male Domination," in Republicanism and Political Theory, ed. by Cécile Laborde \& John Maynor (London: Routledge, 2008), pp. 246-68.

${ }^{44}$ Quentin Skinner, The Foundations of Modern Political Thought Vol. 1: The Renaissance (Cambridge: Cambridge University Press, 1978), pp. 44-45.

45 Blair Worden, "Marchamont Nedham and the Beginnings of English Republicanism, 1649-1656," in Republicanism, Liberty, and Commercial Society, 1649-1776, ed. by David Wootton (Stanford: Stanford University Press, 1994), pp. 45-81, at p. 46. Also David Miller, "Republicanism, National Identity, and Europe," in Republicanism and Political Theory, ed. by Cécile Laborde \& John Maynor (London: Routledge, 2008), pp. 133-58, at pp. 140-43.
} 
against the corruption of the state. ${ }^{46}$ Civic virtue requires both leaders and citizens to abstain from wrongful interference.

Pettit's account of republicanism is not consistent with the tradition, for he must endorse the institutions-only approach. As described by Skinner, these approaches make competing claims about how to sustain effective governance over time. For Pettit, the more specific question is whether institutions or virtues are dominant in ensuring that the members of a political community are free. The Externally Controlled Will Requirement precludes the possibility of relying on civic virtue. One enjoys republican freedom only if there is an institutional arrangement that ensures that one is not vulnerable to anyone's decision to invade or not to protect one. The relation between Pettit's theory and the republican tradition was always one of revision, and not merely of recovery and refinement. But because of the Externally Controlled Will Requirement, the relation may be that of displacement, under the badge of continuity.

The more general lesson of my argument is that, to be free, one relies on others' civic virtue. This is true according to any conception of freedom on which one is free only if, for whatever available option, one would be able to undertake it if one were to choose it. ${ }^{47}$ At least, this is true if we make the following assumptions. When one lives among other people,

\footnotetext{
${ }^{46}$ Marcus Tullius Cicero, On Duties, ed. by M. T. Griffin and E. M. Atkins (Cambridge: Cambridge University Press, 1991), p. 33; Richard Dagger, Civic Virtues: Rights, Citizenship and Republican Liberalism (Oxford: Oxford University Press, 1997); Iseult Honahan, Civic Republicanism (London: Routledge, 2002); Cécile Laborde, Critical Republicanism: The Hijab Controversy and Political Philosophy (Oxford: Oxford University Press, 2008), p. 10.

${ }^{47}$ Hobbes' austere notion of freedom, which Pettit terms 'actualism', does not require this. According to the actualist, I am free if I am able to do what I choose to. Others' virtue may then be irrelevant: on this account, if I choose to hide at the back of a cave, and others cannot find me, I am free. As Pettit notes, actualism is a limit case; "Freedom and Probability," pp. 211-12.
} 
there is no institutional structure that can ensure that no group has the collective power to invade one. One must rely on their civic virtue not to do so. Assume that the temptation to invade others is a widespread and permanent feature of human nature, so that, for example, self-interest, indifference, and unthinking conformity to expectations are by themselves insufficient motives for people to restrain themselves from invading. Sympathy, or moral commitment, is also required. Assume, further, that the internal resistance to such temptation is appropriately termed 'civic virtue'. This is not the full-fledged civic version proposed by the republican tradition, but it is the start of it. One's freedom can be sufficiently assured only if civic virtue is sufficiently widespread. As a general constraint on freedom, the Externally Controlled Will Requirement must be rejected. ${ }^{48}$ Republicanism could be repaired. But if one is dominated merely by being under the power of another, the repair must be made without conceiving of freedom as non-domination. ${ }^{49}$

\footnotetext{
${ }^{48}$ There could be a separate argument for the impossibility of republican freedom, which shows that dyadic domination is inevitable, whether by individuals or the state. That would also show that the Externally Controlled Will Requirement is false, and justify the same conclusion.

${ }^{49}$ For comments and criticism on earlier versions, I am grateful to Paul Billingham, Cécile Fabre, Nik Kirby, David Miller, Philip Pettit, and Tom Sinclair; and especially the Editor, Associate Editors, and Jeff McMahan, for exceptionally thorough criticism.
} 